\title{
Quality Measurement: A comparison of two Methods of Assessment
}

S. Ransdell and B. Lavelle

\section{Q OpenEdition \\ 1 Journals}

\section{Electronic version}

URL: http://journals.openedition.org/cpl/208

DOI: $10.4000 / \mathrm{cpl} .208$

ISSN: $1379-6100$

\section{Publisher}

Centre PsyCLÉ

\section{Printed version}

Date of publication: 1 August 2002

\section{Electronic reference}

S. Ransdell and B. Lavelle, "Quality Measurement: A comparison of two Methods of Assessment », Current psychology letters [Online], 2002/2, 8 | 2002, Online since 05 September 2003, connection on 08 September 2020. URL : http://journals.openedition.org/cpl/208; DOl : https://doi.org/10.4000/cpl. 208

This text was automatically generated on 8 September 2020

(C) All rights reserved 


\section{Quality Measurement: A comparison of two Methods of Assessment}

S. Ransdell and B. Lavelle 